\title{
Multidisciplinary investigation on cold seeps with vigorous gas emissions in the Sea of Marmara (MarsiteCruise): Strategy for site detection and sampling and first scientific outcome
}

Livio Ruffine $^{\mathrm{a}, *}$, Hélène Ondreas ${ }^{\mathrm{a}}$, Marie-Madeleine Blanc-Valleron ${ }^{\mathrm{b}}$, Barbara M.A. Teichert ${ }^{\mathrm{c}}$, Carla Scalabrin ${ }^{\mathrm{a}}$, Emmanuel Rinnert ${ }^{\mathrm{a}}$, Dominique Birot ${ }^{\mathrm{a}}$, Claire Croguennec ${ }^{\mathrm{a}}$, Emmanuel Ponzevera $^{\mathrm{a}}$, Catherine Pierre ${ }^{\mathrm{d}}$, Jean-Pierre Donval ${ }^{\mathrm{a}}$, Anne-Sophie Alix ${ }^{\mathrm{a}}$, Yoan Germain ${ }^{\mathrm{a}}$, Laurent Bignon ${ }^{\mathrm{a}}$, Joel Etoubleau ${ }^{\mathrm{a}}$, Jean-Claude Caprais ${ }^{\mathrm{a}}$, Joel Knoery ${ }^{\mathrm{e}}$, Françoise Lesongeur ${ }^{\mathrm{a}}$, Bastien Thomas ${ }^{\mathrm{e}}$, Angélique Roubi ${ }^{\mathrm{a}}$, Ludovic Nicolas Legoix ${ }^{\mathrm{a}, \mathrm{f}}$, Pete Burnard $^{\mathrm{g}, 1}$, Nicolas Chevalier ${ }^{\mathrm{c}, \mathrm{d}}$, Hailong Lu ${ }^{\mathrm{h}}$, Stéphanie Dupréa ${ }^{\mathrm{a}}$, Christophe Fontanier ${ }^{\mathrm{a}, \mathrm{i}, \mathrm{j}, \mathrm{k}}$, Delphine Dissard ${ }^{\mathrm{d}}$, Nazli Olgun ${ }^{1}$, Hailin Yang ${ }^{\mathrm{h}}$, Harald Strauss ${ }^{\mathrm{c}}$, Volkan Özaksoy ${ }^{\mathrm{m}}$, Jonathan Perchoc $^{\mathrm{n}}$, Christian Podeur ${ }^{\mathrm{a}}$, Corinne Tarditi ${ }^{\mathrm{a}}$, Eyyüp Özbeki ${ }^{\mathrm{m}}$, Vivien Guyader ${ }^{\mathrm{a}}$, Bernard Marty $^{g}$, David Madre ${ }^{g}$, Mathilde Pitel-Roudaut ${ }^{\mathrm{a}}$, Céline Grall ${ }^{\circ}$, Davide Embriaco ${ }^{\mathrm{p}}$, Alina Polonia ${ }^{\mathrm{q}}$, Lucas Gasperini ${ }^{\mathrm{q}}$, M. Namik Çağatay ${ }^{\mathrm{r}}$, Pierre Henry ${ }^{\mathrm{s}}$, Louis Géli ${ }^{\mathrm{a}}$

a IFREMER, Département Ressources Physiques et Ecosystèmes de fond de Mer (REM), 29280 Plouzané, France

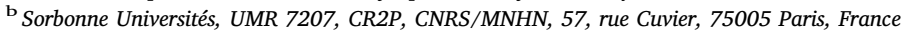

${ }^{\mathrm{c}}$ Westfälische Wilhelms-Universität Münster, Institut für Geologie und Paläontologie, D-48149 Münster, Germany

d Sorbonne Universités, UPMC, CNRS, IRD, MNHN, IPSL, LOCEAN, Paris, France

e IFREMER, Département Ressources Biologiques et Environnement (RBE), Unité Biogéochimie et Ecotoxicologie, F-44311 Nantes Cedex 03, France

${ }^{\mathrm{f}}$ GEOMAR, Helmholtz Centre for Ocean Research Kiel, Wischhofstr. 1-3, D-24148 Kiel, Germany

${ }^{8}$ Université de Lorraine, CNRS, Ctr Rech Petrog \& Geochim, F-54500 Vandoeuvre Les Nancy, France

${ }^{\mathrm{h}}$ Peking University, Department of Energy \& Sciences, College of Engineering, Beijing 100871, China

${ }^{\text {i }}$ FORAM, Foraminiferal Study Group, F-49140 Villevêque, France

${ }^{\mathrm{j}}$ Université d'Angers, F-49035 Angers, France

${ }^{\mathrm{k}}$ Université de Bordeaux, CNRS, Environnements et Paléo-environnements Océaniques et Continentaux, UMR 5805, F-33600 Pessac, France

${ }^{1}$ Istanbul Technical University, Eurasia Institute of Earth Sciences, Climate and Marine Sciences, Maslak, TR-34469 Istanbul, Turkey

${ }^{\mathrm{m}}$ Marine and Environmental Research Department, General Directorate of Mineral Research and Exploration (MTA), Üniversiteler Mahallesi, Dumlupinar Bulvarı No:139, 06800 Çankaya/Ankara, Turkey

n IFREMER, Dyneco BENTHOS, 29280 Plouzane, France

Lamont-Doherty Earth Observatory of Columbia University, Palisades, NY, USA

P Istituto Nazionale di Geofisica e Vulcanologia (INGV), Via di Vigna Murata, 605, 00143 Roma, Italy

${ }^{\mathrm{q}}$ Istituto di Scienze Marine, ISMAR-CNR, Marine Geology, Bologna, Italy

${ }^{\mathrm{r}}$ Istanbul Technical University, Faculty of Mines, EMCOL and Dept of Geological Engineering, TR-34469 Istanbul, Turkey

s Aix-Marseille Univ., CNRS, IRD, Coll. France, CEREGE, Aix-en-Provence, France

\section{A R T I C L E I N F O}

\section{Keywords:}

Acoustic survey

Authigenic carbonates

Biogeochemistry

Chemical analyses

Cold seeps

Dissolved major elements

Fluid seepage

Geology

In situ Raman analysis

\section{A B S T R A C T}

MarsiteCruise was undertaken in October/November 2014 in the Sea of Marmara to gain detailed insight into the fate of fluids migrating within the sedimentary column and partially released into the water column. The overall objective of the project was to achieve a more global understanding of cold-seep dynamics in the context of a major active strike-slip fault. Five remotely operated vehicle (ROV) dives were performed at selected areas along the North Anatolian Fault and inherited faults.

To efficiently detect, select and sample the gas seeps, we applied an original procedure. It combines sequentially (1) the acquisition of ship-borne multibeam acoustic data from the water column prior to each dive to detect gas emission sites and to design the tracks of the ROV dives, (2) in situ and real-time Raman spectroscopy analysis of the gas stream, and (3) onboard determination of molecular and isotopic compositions of the

\footnotetext{
* Corresponding author.

E-mail address: livio.ruffine@ifremer.fr (L. Ruffine).

${ }^{1}$ Deceased.
} 
Methane

ROV dives collected gas bubbles. The in situ Raman spectroscopy was used as a decision-making tool to evaluate the need for continuing with the sampling of gases from the discovered seep, or to move to another one. Push cores were gathered to study buried carbonates and pore waters at the surficial sediment, while CTD-Rosette allowed collecting samples to measure dissolved-methane concentration within the water column followed by a comparison with measurements from samples collected with the submersible Nautile during the Marnaut cruise in 2007.

Overall, the visited sites were characterized by a wide diversity of seeps. $\mathrm{CO}_{2}$ - and oil-rich seeps were found at the westernmost part of the sea in the Tekirdag Basin, while amphipods, anemones and coral populated the sites visited at the easternmost part in the Cinarcik Basin. Methane-derived authigenic carbonates and bacterial mats were widespread on the seafloor at all sites with variable size and distributions. The measured methane concentrations in the water column were up to $377 \mu \mathrm{mol}$, and the dissolved pore-water profiles indicated the occurrence of sulfate depleting processes accompanied with carbonate precipitation. The pore-water profiles display evidence of biogeochemical transformations leading to the fast depletion of seawater sulfate within the first 25-cm depth of the sediment. These results show that the North Anatolian Fault and inherited faults are important migration paths for fluids for which a significant part is discharged into the water column, contributing to the increase of methane concentration at the bottom seawater and favoring the development of specific ecosystems.

\section{Introduction}

On continental margins, cold seeps refer to specific areas where methane-rich fluids are emitted at the seafloor either by seepage or by venting (Boetius and Wenzhofer, 2013; Suess, 2014; Talukder, 2012). Methane is transported from the deep subsurface or generated at shallow sedimentary depth, and is discharged at the seafloor either as dissolved phase or as free gas mixtures. The transport pathway is generally controlled by the cold-seep plumbing system (Talukder, 2012). During their ascent through the sedimentary column, the methane-rich fluids undergo physical and chemical transformations. When the ad hoc temperature and pressure conditions are met, the main physical transformation corresponds to the formation of gas hydrates in the sedimentary column. This process represents the major methane storage on earth (Kvenvolden, 1988), while methane oxidation is the chemical transformation that prevents or mitigates its release into the water column. Indeed, methane oxidation is never complete and part of the ascending fluids is released into the water column, which may create acoustic anomalies, so-called "gas plumes" of tens to thousands of meters height (Mau et al., 2017; Westbrook et al., 2009). Thus, oxidation constitutes by far the most important methane mitigation process at cold seeps. In anaerobic environment, this oxidation is coupled with the reduction of seawater sulfate. It is commonly called the Anaerobic Oxidation of Methane (AOM), and is expressed as follows:

$\mathrm{CH}_{4}+\mathrm{SO}_{4}{ }^{2-}=>\mathrm{HCO}_{3}^{-}+\mathrm{HS}^{-}+\mathrm{H}_{2} \mathrm{O}$

This reaction is a good example showing the intimate link between carbon (hydrocarbon and carbonates) and sulfur (sulfate and sulfide) cycles at cold seeps (Deusner et al., 2014; Holler et al., 2011, 2012; Lin et al., 2016). Spatial and temporal differences in sulfide and methane fluxes in the topmost sediment induce an obvious biozonation of chemoautotrophic prokaryotes and a patchy distribution of benthic eukaryotes (Foucher et al., 2009; Sahling et al., 2002; Sibuet and Olu, 1998).

Cold seeps have been investigated for decades owing to their importance in the cycles of a large variety of chemical elements and compounds, and in terms of both benthic microbiota and meiofauna (e.g. benthic foraminifera) (Sassen et al., 1993; Suess, 2014; Zitter et al., 2008). In particular, methane is a key chemical element of cold seeps as it plays an important role in the carbon cycle although its role is not fully understood and constrained. A first step to improve our understanding of cold seeps is to be able to detect rapidly such areas, and then to efficiently define the sampling strategy by relying on real-time measurement of key parameters.

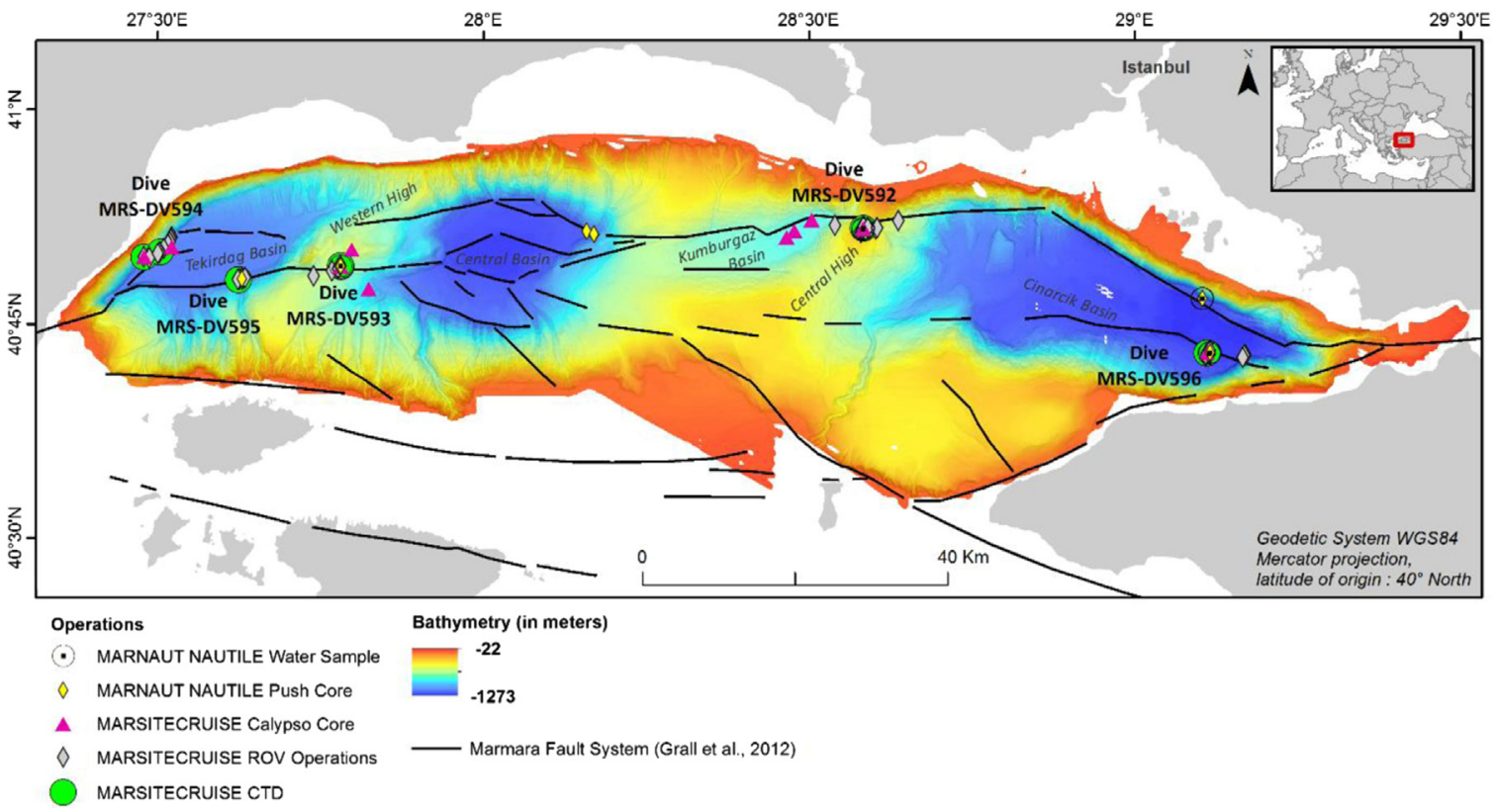

Fig. 1. Location map of the ROV dives and distribution of the samples collected. 
The present article describes an original procedure to efficiently detect, select and sample seafloor fluid emissions at cold-seeps characterized by gas emissions. This procedure is based on prerequisite regional acoustic surveys of the investigated area (Dupré et al., 2015), and has been applied to investigate five immerged segments of the North Anatolian Fault (NAF) and inherited faults in the Sea of Marmara (SoM). An overview of the five dives is also presented to illustrate the results, with an emphasis on the methane distribution in the bottom water and the geochemical processes occurring near the sediment-water interface in the first $25 \mathrm{~cm}$ below seafloor (cmbsf).

\section{Study area, strategy for seep recognition and in situ sampling}

The Sea of Marmara (SoM) is a highly faulted sedimentary basin (Fig. 1) crossed lengthwise by the North Anatolian Fault. The latter is a very active fault, which was responsible for several devastating earthquakes in the past, including the $1999 \mathrm{Mw}=7.4$ earthquake which ruptured the entire segment of the Gulf of Izmit, in the east end of the SoM (Gasperini et al., 2011). The SoM consists of three main basins, which are sequentially called from east to west Cinarcik Basin, Central Basin and Tekirdag Basin. These basins are separated by two highs, Western High and Central High (Fig. 1). The location of the fluid emission zones along the NAF system is well documented from results of previous regional acoustic surveys (Dupré et al., 2010, 2015; Géli et al., 2008). However, during the MarsiteCruise, a reliable seep-recognition procedure was required to validate the persistence of the fluid emissions and to overcome the difficulties related to the in situ localization of these emissions owing to the narrow field of view of the ROV (limited to 5-10 $\mathrm{m}$ wide). The seep-recognition procedure was based on acoustic surveys and in situ gas composition assessment, followed by onboard chemical analyses. Thus, first, a water column acoustic survey was conducted along the predefined ROV track prior to each dive, rapidly followed by a data processing to identify the location of anomalies related to gas releases. A classification of the acoustic anomalies was done regarding their intensity. Thus, the stronger ones were selected to refine the ROV track and allow visiting them. The first source visited and sampled during Dive MRS-DV594 (DV3) on the western flank of the Tekirdag Basin is an example of ROV-track tuning using acoustic. The strong echo observed during the acoustic survey (Fig. 2A) leaded to changes in the dive track and this source turned out to be the only one that was mainly composed of $\mathrm{CO}_{2}$ (Ruffine et al., In this issue). Another example is the acoustic validation of fluid emission persistence in the Boris Bubbler site (Fig. 2B), which is known to expel fluids rich in mantle He since it was sampled during the Marnaut cruise in 2007 (Burnard et al., 2012; Ruffine et al., In this issue). Such a procedure prior to the dives turned out to be very efficient for fast detection of fluid seeps. Second, during the ROV-dives, a fast selection of the gas streams from the seeps to be studied was made by measuring its composition with an in situ Raman-spectrometer. It is a homemade in situ instrument, which was already described in previous a work (Peron et al., 2010). It was adapted for gas measurements by the implementation of a $532 \mathrm{~nm}$ DPSS laser (Integrated Optics) and by the development of a specific gas probe. It was also implemented on the ROV Victor 6000 (Fig. 3A). The probe is equipped with a cone that leads the gas bubbles to the measurement cell. It is placed above the seep with the automated arm of the ROV (Fig. 3B). After the selection of the gas stream, a sample was taken with the PEGAZ sampler (Ruffine et al., In this issue). The same procedure was performed for another gas streams nearby, and sample was collected only if we observed differences in the physicochemical properties or on the chemosynthetic communities of the two consecutively analyzed gas streams. When necessary, and to complete the in situ molecular measurement, methane stable-carbon isotope was analyzed onboard with an analyzer G2201-i Cavity Ring-Down Spectrometer (CRDS) coupled with a SSIM2 module (Small Sample Isotope Module 2) from Picarro.

Push cores were taken afterward both at gas emission sites and at large bacterial mats characterized by an absence of gas emissions to collect surficial sediments for pore-water, buried-carbonate and sediment analyses. Outcropping carbonates were directly collected at the seafloor. The ROV dives were followed by the deployment of a CTDRosette at the visited site where the most vigorous gas streams were measured to complete our set of samples and data. Fluids and sediment were also collected using titanium syringe, blade cores and Calypso piston-cores; however, these samples will not be discussed in the present paper. The overall collected samples are summarized in Table 1.

\section{Material and method}

\subsection{Acoustic data acquisition and processing}

Acoustic data were acquired with the ship-borne RESON 7150 multibeam echo sounder using the $24 \mathrm{kHz}$ frequency with 880 beams $\left(0.5^{\circ} \times 0.5^{\circ}\right.$ beam-width $)$ and an average vessel speed of 6 knots. The vertical resolution of water column data varies between 1.5 and $6 \mathrm{~m}$ respectively to the pulse lengths of $2-8 \mathrm{~ms}$ used during the surveys. The mean echo positioning error in the across-track direction varies between 2 and $10 \mathrm{~m}$ while the inter-ping distance in the along-track direction is within the $5-15 \mathrm{~m}$ interval for water depths between 200 and $1200 \mathrm{~m}$. Water column processing was performed onboard with SonarScope and GLOBE softwares (C) Ifremer).

\subsection{Raman spectrum processing}

The accumulation time was of $\sim 60 \mathrm{~s}$ and each spectrum was made from two accumulations. Examples of spectra acquired during Dive MRS-DV594 (DV03-RA05) are shown in Fig. 4A. On both spectra from the seawater and gas seep, a band located at $895 \mathrm{~cm}^{-1}$ is due to an internal reference, which is used to calibrate the wavelength and to control the intensity and the sensitivity of the spectrometer. Fig. 4B shows the stability of this band. In this figure, a band located at $980 \mathrm{~cm}^{-1}$ in the water spectrum is assigned to the sulfate stretching mode. This band disappears when the measurement cell is filled by the gas (black curve). The stretching modes of water molecules are observed in Fig. 4C at 3235 and $3395 \mathrm{~cm}^{-1}$. Finally, the black curve in
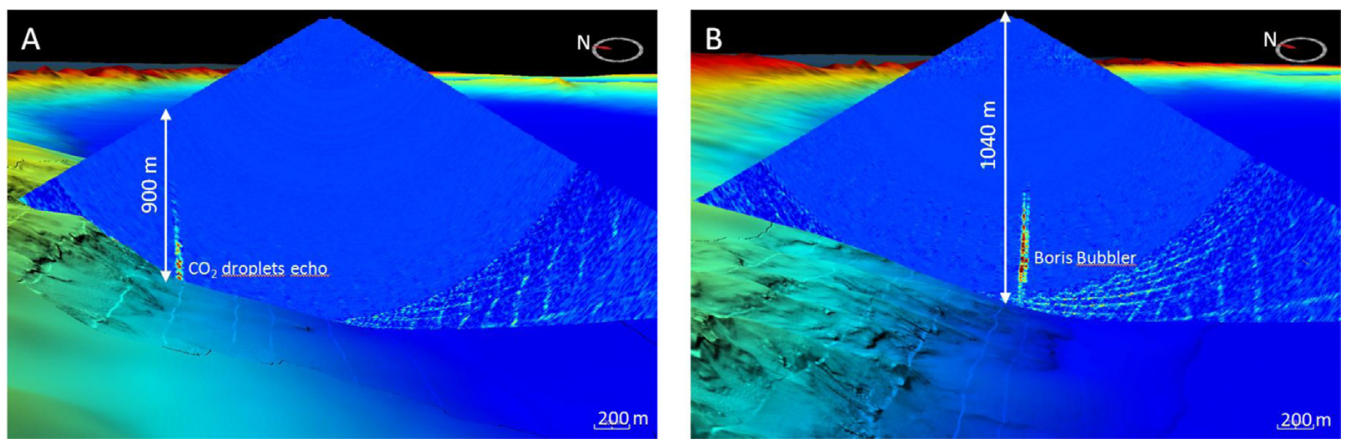

Fig. 2. (A) water column polar echogram showing the $\mathrm{CO} 2$ source echo corresponding to the sample MRS-DV3-PE03. The root of the echo in the seafloor is located at 900 mbss and its visible height is $\sim 386 \mathrm{~m}$. (B) water column polar echogram showing the Boris Bubbler echo corresponding to the sample MRS-DV3-PE06. The root of the echo in the seafloor is located at $1040 \mathrm{mbss}$ and its visible height is $\sim 463 \mathrm{~m}$. 


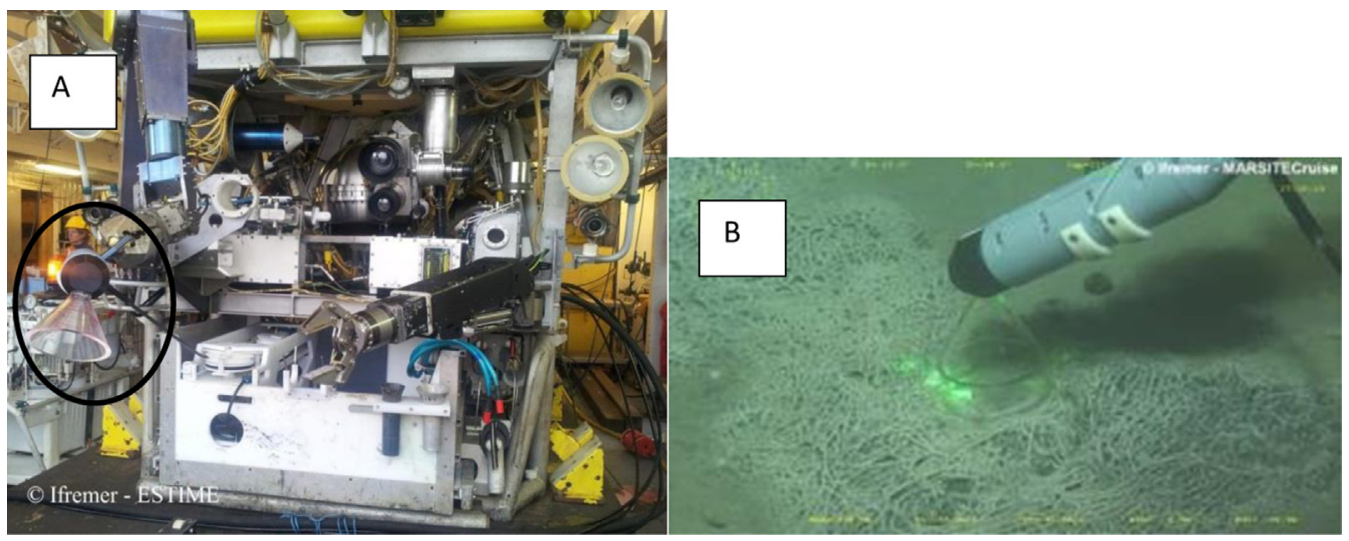

Fig. 3. (A) picture of the Raman spectrometer implemented on the Victor 6000 ROV (black ellipse) and (B) picture of the gas probe during a measurement.

Table 1

Summary of the collected samples.

\begin{tabular}{llllllllll}
\hline & Raman & PEGAZ & Flow & Ti & PC & BC & CS & CTD & Carbonates \\
\hline $\begin{array}{l}\text { MRS-DV592 } \\
\text { (DV01) }\end{array}$ & 5 & 2 & 11 & 1 & 8 & & 3 & 1 & 3 \\
$\begin{array}{l}\text { MRS-DV593 } \\
\text { (DV02) }\end{array}$ & 2 & 2 & 2 & 1 & 8 & & 3 & 2 & 2 \\
$\begin{array}{l}\text { MRS-DV594 } \\
\text { (DV03) }\end{array}$ & 8 & 6 & 14 & 2 & 8 & 1 & 3 & 2 & 3 \\
$\begin{array}{l}\text { MRS-DV595 } \\
\text { (DV04) }\end{array}$ & 5 & 3 & 5 & 1 & 4 & & - & 2 & 2 \\
$\begin{array}{l}\text { MRS-DV596 } \\
\text { (DV05) }\end{array}$ & 8 & 4 & 9 & 2 & 7 & 1 & 2 & 1 & 2 \\
Total & 28 & 17 & 41 & 7 & 35 & 2 & 11 & 8 & 12 \\
\hline
\end{tabular}

Raman refers to in situ gas bubbles analysis using a Raman spectrometer; PEGAZ to gas bubble sampling; Flow to in situ flow measurement; Ti to fluid sampling from titanium bottle; PC to push-core, BC to blade core, CS to long-gravity Calypso core, CTD to the CTD equipped with a Rosette for water sampling, Carbonates to the recovery of carbonate crusts.

Fig. 4C shows several bands assigned to hydrocarbon molecules; the major one at $2917 \mathrm{~cm}^{-1}$ referred to methane. The band observed at 3016 and $3068 \mathrm{~cm}^{-1}$ are likely due to aromatic compounds. Furthermore, the weak band located at $2578 \mathrm{~cm}^{-1}$ is assigned to $\mathrm{H}-\mathrm{S}$ bonds.

\subsection{Water and carbonate sampling, and geochemical analyses}

Pore waters were extracted from the rounded push-cores using Rhizon samplers (Seeberg-Elverfeldt et al., 2005), and collected in precleaned syringes of $10 \mathrm{~mL}$. The samples were stored in $15 \mathrm{~mL}$ HDPE vials and kept at $4{ }^{\circ} \mathrm{C}$ for geochemical analyses. Subsamples for major and minor element analyses were acidified with $15 \mu$ lof concentrated $\mathrm{HNO}_{3}$. Total alkalinity (Alk) were measured on board directly after sampling by titration with $0.1 \mathrm{~N} \mathrm{HCl}$ on a potentiometric titrator 848 Tritrino Plus from Metrohm ${ }^{\oplus}$. The uncertainty in measurement was $<$ $5 \%$. Major element analysis was carried out on an ion-exchange chromatograph Dionex ICS-5000 from Thermo Scientific ${ }^{\oplus}$, equipped with an electrical conductivity detector while minor dissolved-elements were analyzed by High Resolution Inductively Coupled Plasma Mass Spectrometry (HR-ICP-MS Element2, Thermo Scientific ${ }^{\circledast}$ ). IAPSO standard seawater was used as certified reference material for the calibration of the major elements, and the uncertainty was less than $3 \%$. For the minor elements, the standard addition method using NASS- 5 standard seawater was successfully performed with an accuracy within $\pm 4 \%$.

Concentrations of pore water hydrogen sulfide were determined onboard by spectrophotometry as methylene blue complex following the method of Cline (Cline, 1969). Pore water was subsampled and directly transferred into Eppendorf vials with $100 \mu \mathrm{l}$ of gelatinous zinc acetate solution to stabilize the sulfide. Different dilutions were
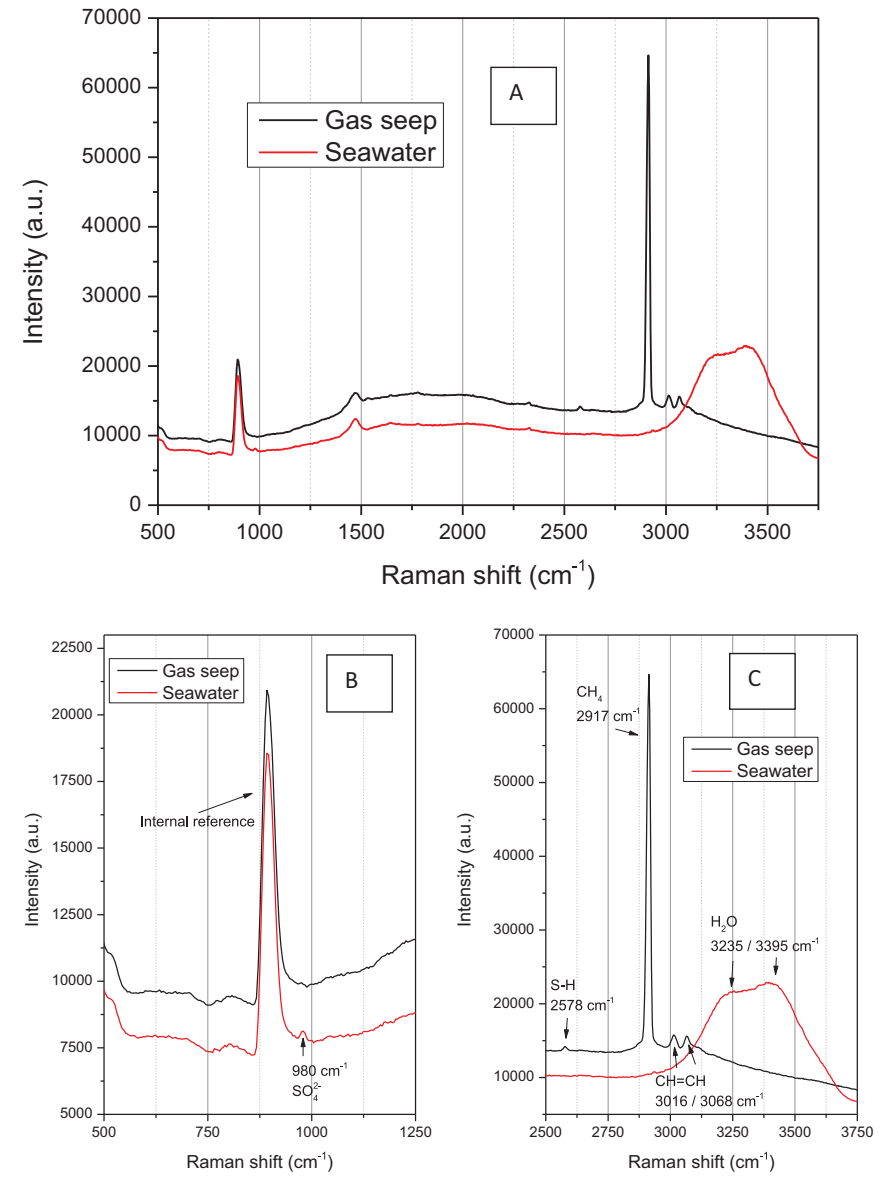

Fig. 4. (A) Raman spectra of seawater (red) and of gas (black) during the dive 594 (DV03 RA05). Enlargement on low Raman shift (B) and on high Raman shift (C).

prepared $(1: 1,1: 10,1: 100,1: 200)$ with oxygen-free water. Subsequently, $100 \mu \mathrm{l}$ of color reagent (N, N-dimethyl-p-phenylenediamine dihydrochloride solution) and $100 \mu$ of catalyst (Fe(III) solution) were added. After $1 \mathrm{~h}$, absorbance was measured using a Thermo Scientific Genesys 10uv Scanning spectrophotometer at $670 \mathrm{~nm}$ using $1 \mathrm{~cm}$ cuvettes.

Bottom water was collected from CTD-Rosette, and stored in 10-mL glass vials. Methane concentrations were measured by headspace gaschromatography, with an instrument Perichrom 2100 equipped with a flame ionisation detector connected to a headspace injector (Dani HSS 86.50). 


\subsection{Carbonates}

Carbonate concretions were first rinsed with distilled water, to remove salts and sediments. Dried samples were powdered for carbonate mineralogical and isotope analyses, and crushed for chips for Scanning Electron Microscope (SEM) observations, following standard procedures as described in a recent work by Pierre et al. (2017).

\section{Results and discussion}

\subsection{Dive overview}

Numerous sites of fluid venting were observed all along the track of
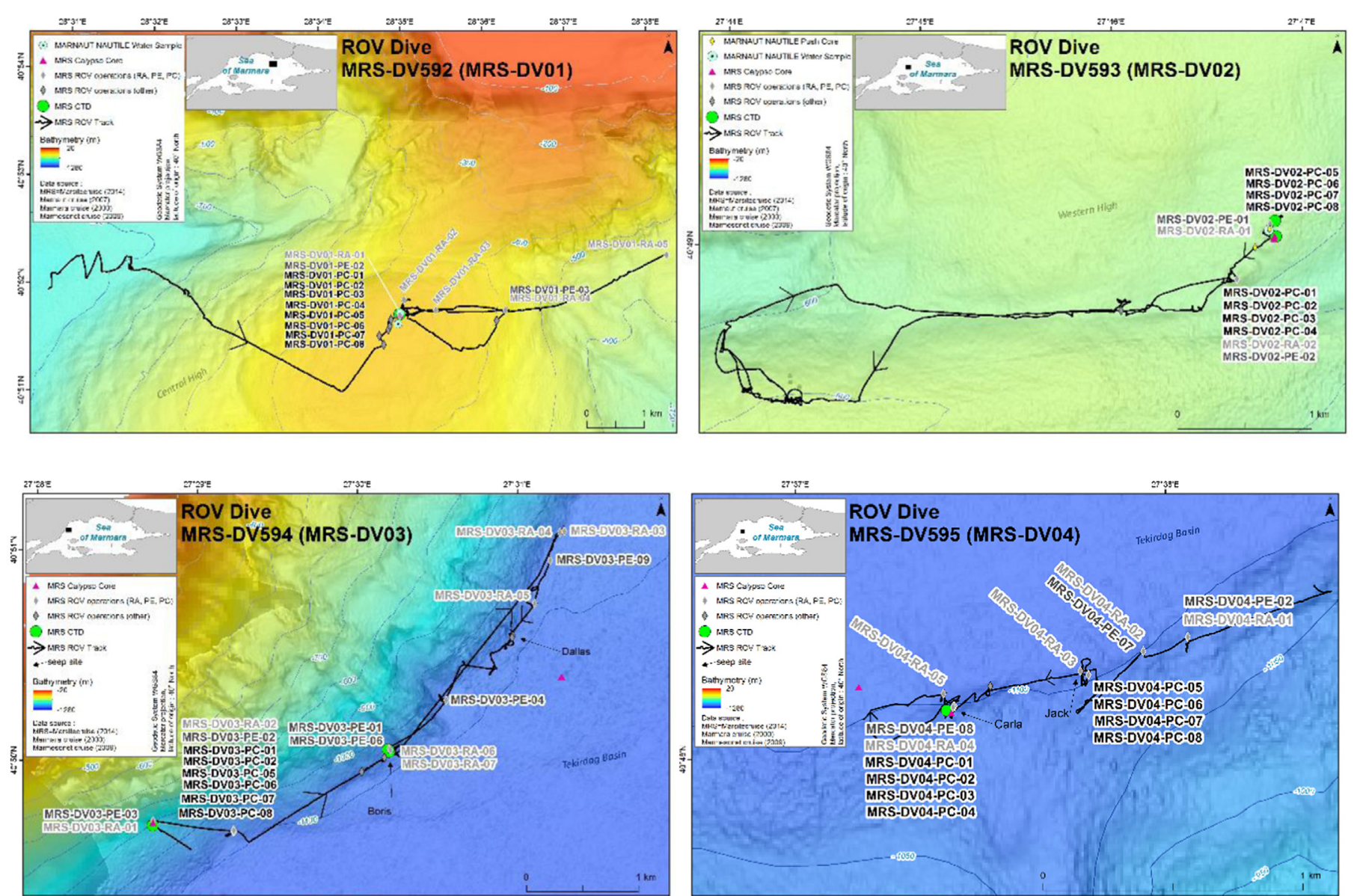

the MarsiteCruise dives.

\subsubsection{Dive MRS-DV592 on the Central High}

Dive MRS-DV592 started south to the NAF at the border of the Kumburgaz Basin, and moved eastward toward the Central High (Fig. 5). The dive stopped at the northeastern foot of the high, north to the NAF. The water column was cloudy with floating particles, leading to a restricted visibility of the sea bottom. All along the dive, the seafloor at the gas seeps was very diverse in color and textural aspects, with black reduced sediment patches of variable sizes ranging from few meters to tens of meter square.

Black patches, bacterial mats and carbonate crusts were not observed when crossing the fault. On the western flank of the Central

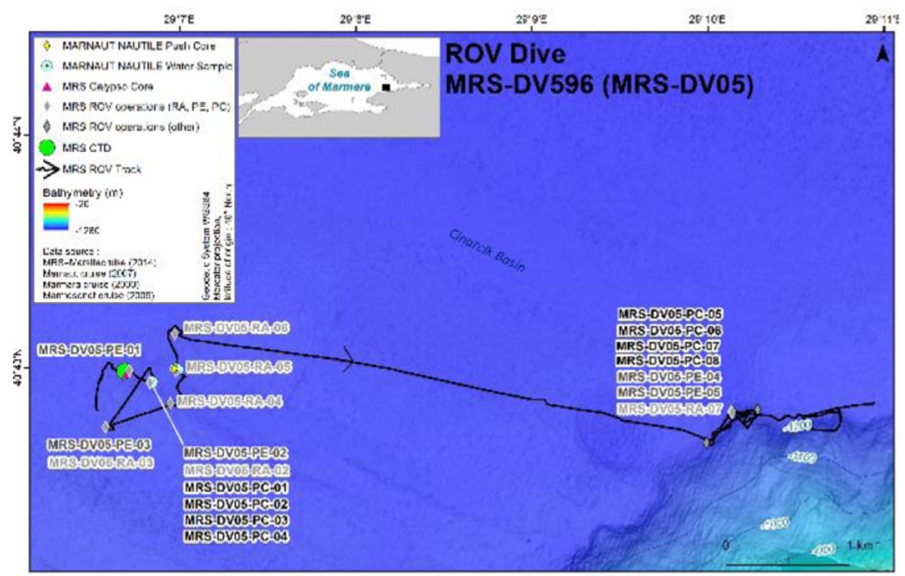
. 
High, a small depression of $100-\mathrm{m}$ in diameter was covered with numerous carbonate crusts (Fig. 6A) and black patches associated with bacterial mats and fauna. Active vents were not observed with naked eye. At half way of the NW slope, intermittent bubble sites were observed but the strongest bubbling activity was found at the summit of the high, with more than 10 gas escapes observed. Numerous black patches were found covered with specific white spaghetti-like bacterial mats (Fig. 6B). Several gas streams were bubbling from small visible vents; some of them were characterized by a short lifetime. The seafloor appearance suggests that the area is characterized by a high sediment deposition rate, with authigenic carbonate crusts that barely appear, or were simply buried beneath a thin sediment layer.

On the NE slope, few focalized seeps with bacterial mat were characterized by low or discontinuous fluid escapes. From visual observations, it was possible to see the escapes showing irregular pulses, with quick shifts from one vent to another.

At the end of the dive near the NAF, few irregular and low fluxes of fluid escapes were present at the foot of the high in its northeastern
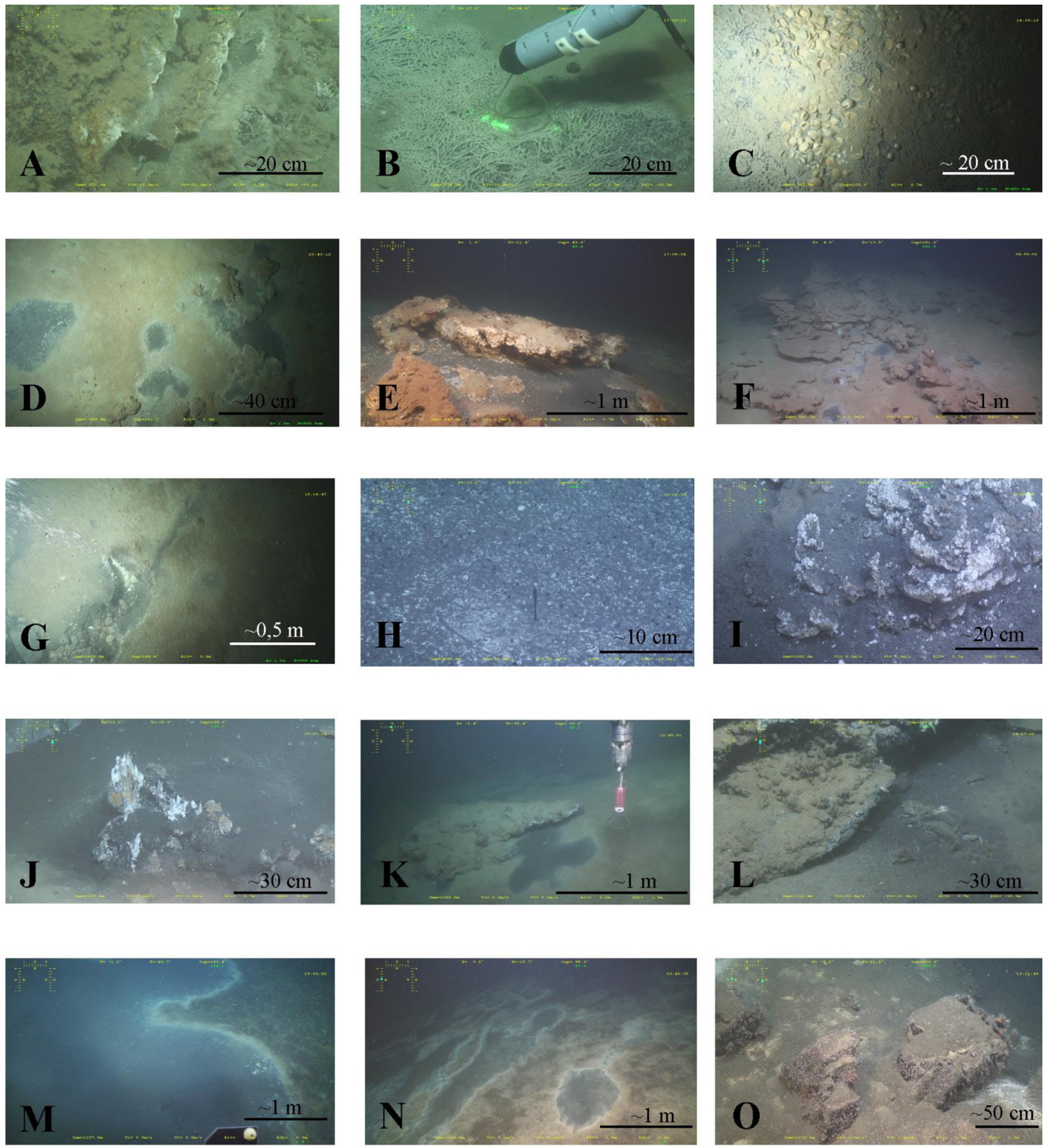

Fig. 6. Photos selected from the ROV dives and characterizing the study sites:. 
part. Outside the seep areas, the seafloor was covered with hemipelagic sediment where urchins were scattered and unevenly distributed. Overall, the fauna consisted of dead and alive urchins, clams in the gas seeping areas and worms in the reduced sediment areas. At some sites, dense accumulation of bivalve shells, presumably dead, covered the sea bottom (Fig. 6C).

\subsubsection{Dive MRS-DV593 on the Western High}

The dive, conducted from east to west (Fig. 2), started north to the NAF over the two SSW-NNE mounds corresponding to mud volcanoes identified from previous cruises (Crémière et al., 2013; Crémiere et al., 2012; Grall et al., 2013), met the NAF, and then carried on along the fault over $3 \mathrm{~km}$. The last part of the ROV track visited areas located several hundreds of meters south from the NAF. The seeps explored along the Western High dive were of different categories, which correspond to:

- Areas with black sediment, corresponding to reduced zones. There, the patches were either narrow (diameter $<2-3 \mathrm{~m}$ ) or large (diameter $>5 \mathrm{~m}$ )

- Areas with reduced black sediment associated with bacterial mats (narrow or large ones)

- Areas with reduced black sediment associated with both bacterial mats (narrow or large ones) and carbonate crusts (Fig. 6D)

- Large areas of massive carbonate crusts (Fig. 6E), with or without bacterial mats around

- Gas seeps with flow ranging from low (few bubbles per time unit enabling the possibility to estimate the flow by simple visual observation) to strong (continuous flow with a large number of bubbles, see supplementary video), and being continuous or intermittent

- Discontinuous oil seeps.

Supplementary material related to this article can be found online at http://dx.doi.org/10.1016/j.dsr2.2018.03.006.

Outside the seepage areas, brown soft sediment was present with bioturbation as well as dead or alive sea urchins. Seeps were ubiquitous on the small-scale reliefs orientated SSW-NNE, their summits being the more active areas. Carbonate crusts were very patchy over the two mounds but particularly dense at their summits (Fig. 6F).

At the northeastern part of the NE mound, a vigorous gas seep was discovered, also associated with intermittent seeps that discharge small oil droplets into the water column. Along the NAF, seeps characterized by reduced sediment, bacterial mats, carbonate crusts and sometimes few intermittent gas emissions were found alternating with segments without seepage evidence. In the explored southern side of the NAF, and $4 \mathrm{~km}$ southwest from the mud volcano mounds, seeps appeared as focused black patches with bacterial mats and carbonate crusts (Fig. 6F) unevenly distributed. Different discontinuous low flow escapes were distributed on this part of the dive. Fauna in the reduced sediment was composed of tubeworms, bivalve shells and sea urchins, lots of which were dead and few probably alive animals. The fish abundance is higher than in other investigated areas with presence of fish close to the oil seeps.

\subsubsection{Dives MRS-DV594 and MRS-DV595 in the Tekirdag Basin}

Two dives were performed in the Tekirdag Basin: MRS-DV594 at the western flank of the basin, along the submerged part of the compressional Ganos Fault (Le Pichon et al., 2001), and MRS-DV595 for the exploration of the southeastern corner of the basin along the NAF.

The seeps observed during Dive MRS-DV594 were very diverse, with the occurrence of both medium (tens of square meters) and large black sediment patches (several hundreds of square meters), bacterial mats and carbonate crusts. Outside the seep areas, the seafloor was characterized by soft bioturbated sediment.

Along the slope in the southern investigated area, mats made of cottony white material were observed without being sampled. Tryon et al. (2010) suggested that these mats were barite mats.

$\mathrm{A} \mathrm{CO}_{2}$-rich fluid escape (Ruffine et al., This issue), occurring on the slope, is associated with translucent bacterial material (see supplementary video). All along the foot of the slope, exposures of tabular sandstone blocks, probably of the Keşan turbidite formation, were observed associated with seeps. A very active site, located at the crossing between the slope and a canyon, and discovered during Marnaut cruise (Géli et al., 2008) was revisited. This site named "Boris Bubbler" is composed of three very active seeps separated from each other by less than $20 \mathrm{~m}$; they were called "Boubouns", "Chnikov"and "Bulot" (Fig. 6G). During the dive, oil seeps were found at several places. In the $\mathrm{NE}$ part, at the foot of the slope, a wide spreading oil seep emitting discontinuously oil droplets created a cloud of beads (Fig. $6 \mathrm{H}$ ) that rose into the water column (see supplementary video), whereas just nearby, another oil seep named "Dallas" was characterized by continuous flow of oil forming filaments at the sea bottom. Few meters away, bubbling of gas at low flow rate was observed. At the northeastern part of the slope, a seep was discharging a shimmering fluid through small carbonate chimneys (Fig. 6I). Aside the shimmering fluid, either continuously or intermittently gas and oil seeps were observed.

Numerous bivalve shells were found along the dive track, both death and alive. Mussels were present close to both "Boris Bubbler" and the shimmering seeps, in association with carbonate chimneys. Tubeworms were found at a reduced area. Several fishes were often associated with the oil seeps while urchins were chiefly distributed outside the seep areas.

Dive MRS-DV595 was a 2-km length track from east to west along the SE border of Tekirdag Basin. Like for the previous dives, black patches of reduced sediment and bacterial mats delineate the seep-influence area. Carbonate crusts and pavements were present, as well as occurrences of shimmering fluid discharges through carbonate chimneys (Fig. 6J) and gas bubbling into the water column (Fig. 6K). The main seeps were located at the crossing of the foot of the basin slope and the main Marmara fault scarp, and the carbonate chimneys were not far from the outlet of a canyon. At this place, black patches were $\mathrm{N} 80^{\circ}-90^{\circ}$ elongated and the chimneys were aligned along the same direction. "Jack the Smoker" (Fig. 6J), a chimney covered with white and orange microbial mats and discovered during Marnaut cruise (Burnard et al., 2012; Tryon et al., 2010), was revisited. Four hundred meters southwest from the canyon outlet, an active bubbling site, named "Carla" (Fig. 6K) was characterized by corals, anemones and mussels fixed on carbonate crusts (Fig. 6L). Mussels were also present near the carbonate chimneys. Along the track, bivalve shells and tubeworms were found associated with the reduced-sediment areas. Like for Dive MRS-DV594, urchins were present on the surface of the bioturbated hemipelagic sediment outside the seep areas.

\subsubsection{Dives MRS-DV596 in the Cinarcik Basin}

The first part of this dive of more than $6-\mathrm{km}$ length on total took place within the basin, whereas the second part investigated the SE border at the foot of the slope. The seeps consist of large black reduced sediment patches (Fig. 6M) with surface areas of $\sim 100-200 \mathrm{~m}^{2}$, bacterial mats (orange and white) and carbonate crusts. Along the track, gas emissions, from low to strong flow, were observed within the basin and at the foot of the southeastern slope. Within the basin, many seeps consisted of tens of gas streams emitted from different vents located in reduced sediment areas. Visible carbonate crusts exposed on the seafloor were scarce. Locally, bacterial mats appeared as areas of focused white thin filaments around the vent holes in the black reduced seeps. At the basin border near the foot of the slope, seeps were associated with numerous massive carbonate crusts of few meters scale in dimension and black patches often elongated according to the slope direction (Fig. $6 \mathrm{~N}$ ). Outside the seeps, the seafloor consisted of hemipelagic brownish sediment. All along the ROV track, an abundant and 
diversified fauna was observed. Tubeworms seemed to be restricted to the seep areas. Along the SE border at the foot of the slope, numerous animals like amphipods, anemones, corals and crustaceans were present upon and around the carbonate crusts (Fig. 60).

\subsection{Pore-water geochemistry in the surficial sediment}

Push cores were collected at areas characterized by either gas bubbles, bacterial mats, black patches, or no visible activity (here considered as reference site for pore-water chemistry) (Table 2). Depthconcentration profiles of chloride, sulfate, strontium, calcium, barium, manganese, magnesium, sulfide as well as the alkalinity and $\delta^{13} \mathrm{C}$-DIC/ $\% 0$ are presented in Fig. 7. Over the upper $25 \mathrm{~cm}$ of sediment, chloride concentration remained constant, with values close to that of Mediterranean water. There was clearly sulfate depletion at some bubble or oil-seeping sites (MRS-DV02-PC-06, MRS-DV04-PC-01 and MRS-DV05PC-01) as described in Table 2. Dissolved methane was not measured from the pore-water samples. However, methane is the dominant component of the gases bubbling at the seafloor (Ruffine et al., This issue), and previous studies showed that Anaerobic Oxidation of Methane (AOM) is widespread at gas seeps in the SoM (Çağatay et al., 2004; Chevalier et al., 2013; Halbach et al., 2004; Ruffine et al., 2015; Teichert et al., This issue; Tryon et al., 2010). Thus, we believe that $\mathrm{AOM}$ is also responsible for the pore-water sulfate depletion observed at the visited gas bubbling sites, and thus the sulfate-depleted horizon corresponds to the Sulfate-Methane-Transition-Zone (SMZT). This is a common process at methane-rich gas emission sites (Borowski et al., 1996; Chuang et al., 2013; Sultan et al., 2016). The sulfate profiles display SMTZ depths close to the seafloor. At site MRS-DV05-PC-05, sulfate concentrations above the seawater value are probably due to oxidation of HS- produced by the AOM reaction. The SMTZ is shallower than $15 \mathrm{~cm}$ at most of the sampled sites (Fig. 7). At sites MRS-DV01-PC06, MRS-DV03-PC-01 and MRS-DV05-PC-05, however, the SMTZ appears to be deeper. These cores were retrieved outside the bacterial mats and the bubbling sites (Table 2) for reference purpose. The resulting pore-water profiles show that shallow sulfate depletion takes place within the specific features observed on the seafloor. Such results evidence a relatively focused methane migration within the shallow sedimentary column. The SMTZ is characterized by maximum concentrations of alkalinity, sulfide and barium, and minimum in $\delta^{13} \mathrm{C}$-DIC and Ca concentrations (Table 2, Fig. 7). High alkalinity in this zone occurs as a result of the release of bicarbonate ions by the AOM reaction. This leads to authigenic carbonate precipitation at the horizon, which corresponds to a minimum in Ca concentration. Alkalinity is relatively high at sites where the SMTZ is shallow and low where the SMTZ is deep. High dissolved barium concentrations close to the SMTZ are due to the dissolution of barite under reducing and sulfate-depleted conditions. Dissolved barium is particularly high $(\sim 2 \mathrm{mM})$ in core MRS-DV04-PC-01 in SE Tekirdağ Basin, where the SMTZ is shallow.

High dissolved manganese concentrations in pore waters occur in the suboxic zone just above the SMTZ. As a redox-sensitive element, manganese dissolves from the sediments under relatively reducing conditions in the suboxic zone, diffuses upward, and precipitates in the oxic-suboxic interface in the sediments (Calvert and Pedersen, 1993; Sassen et al., 1993; Thomson et al., 2001).

\subsection{Methane concentrations within the water column}

As mentioned previously, apart from a seep at the southwestern part of the Ganos segment in the Tekirdag Basin, methane is the dominant component of the gases emitted in the Sea of Marmara (Bourry et al., 2009; Ruffine et al., This issue). Methane concentrations measured from samples obtained from both CTD-Rosette deployment and Nautile dives are presented in Fig. 8. The measured concentrations from the CTDRosette samples are much lower than those from the Nautile dives. Such a difference reflects the occurrence of a strong gradient in methane concentration at the gas emission sites. In fact, seawater sampling from the Nautile dives allows determining methane concentration tens of centimeters away from the gas streams as it consists on an in situ sampling greatly helped by visual observations. Such an accuracy for reaching the seep target cannot be achieved with a CTD-Rosette deployment from the sea surface. Its positioning depends on multiple parameters (e.g. water depth, stability of the ship at fix point, current distribution within the water column, etc.), and can explain the lower concentrations measured. However, the two sampling tools complement each other as the merged data enable us to appreciate the methane gradient in the water column around the gas seeps. Methane concentrations up to $1.3 \mu \mathrm{M}$ were measured from the CTD-Rosette samples, and values reaching $377 \mu \mathrm{M}$ were obtained in the samples collected from the submersible Nautile. Such high concentrations were measured both on Central High at around $360 \mathrm{~m}$ of water depth and in Cinarcik Basin at around $1200 \mathrm{~m}$ of water depth, and are several orders of magnitude larger than the normal methane concentration in seawater in equilibrium with the atmosphere (around 2-3 nM). This suggests that the high amounts of dissolved methane measured were due to the methane flux from the seafloor which diffuses into the surrounding bottom water. Moreover, intense emissions of methane at the seafloor where the hydrostatic pressure is high above the atmospheric pressure can lead to the dissolution of a greater amount of gas as methane solubility increases with increasing pressure. Besides, methane bubbles might also be likely sampled together with the bottom water, increasing its concentration.

The observed large variability in measurements values is not surprising as methane concentration may vary orders of magnitude in few minutes at the same location (Bayrakci et al., 2014; Embriaco et al., 2014; Ruffine et al., This issue). Moreover measured concentrations are strongly dependent on oceanic conditions (e.g. the bottom current which is responsible for driving fluids from emission site towards the measurement location) and on measurement conditions (e.g. whether the measurement device is sampling a higher or lower volume during the observation time). The high variability with time and the large gradient values observed at a single measurement site suggest that

Table 2

$\mathrm{SO}_{4}{ }^{2-}$-depletion depth, alkalinity and $813 \mathrm{C}$-DIC peaks measured for pore waters extracted from the push cores.

\begin{tabular}{|c|c|c|c|c|}
\hline Sample & Area specificities where the core was collected & $\mathrm{SO}_{4}{ }^{2-}$-depletion depth interval/ $\mathrm{cm}$ & Alkalinity/ $\mu \mathrm{M}$ & \&13C-DIC/\%o \\
\hline MRDS-DV01-PC05 & White bacterial filament with gas bubbles & $6-8$ & 43041 & \\
\hline MRDS-DV01-PC06 & Outside a few meters away from a bacterial mat & - & - & \\
\hline MRDS-DV02-PC04 & Bubble site & $2-6$ & 44630 & -21.34 \\
\hline MRDS-DV02-PC06 & Oil and gas seepage & $5-7$ & 56493 & \\
\hline MRDS-DV03-PC01 & Bacterial mat & - & - & \\
\hline MRDS-DV03-PC06 & Outside and close to a bacterial mat & $13-15$ & 30125 & -30.77 \\
\hline MRDS-DV04-PC01 & Gas bubbles & $4-6$ & - & -36.68 \\
\hline MRDS-DV04-PC06 & Black patch & $3-6$ & 32098 & -34.36 \\
\hline MRDS-DV05-PC01 & Gas bubbles & - & - & \\
\hline MRDS-DV05-PC05 & Close to carbonate crusts & - & - & \\
\hline
\end{tabular}



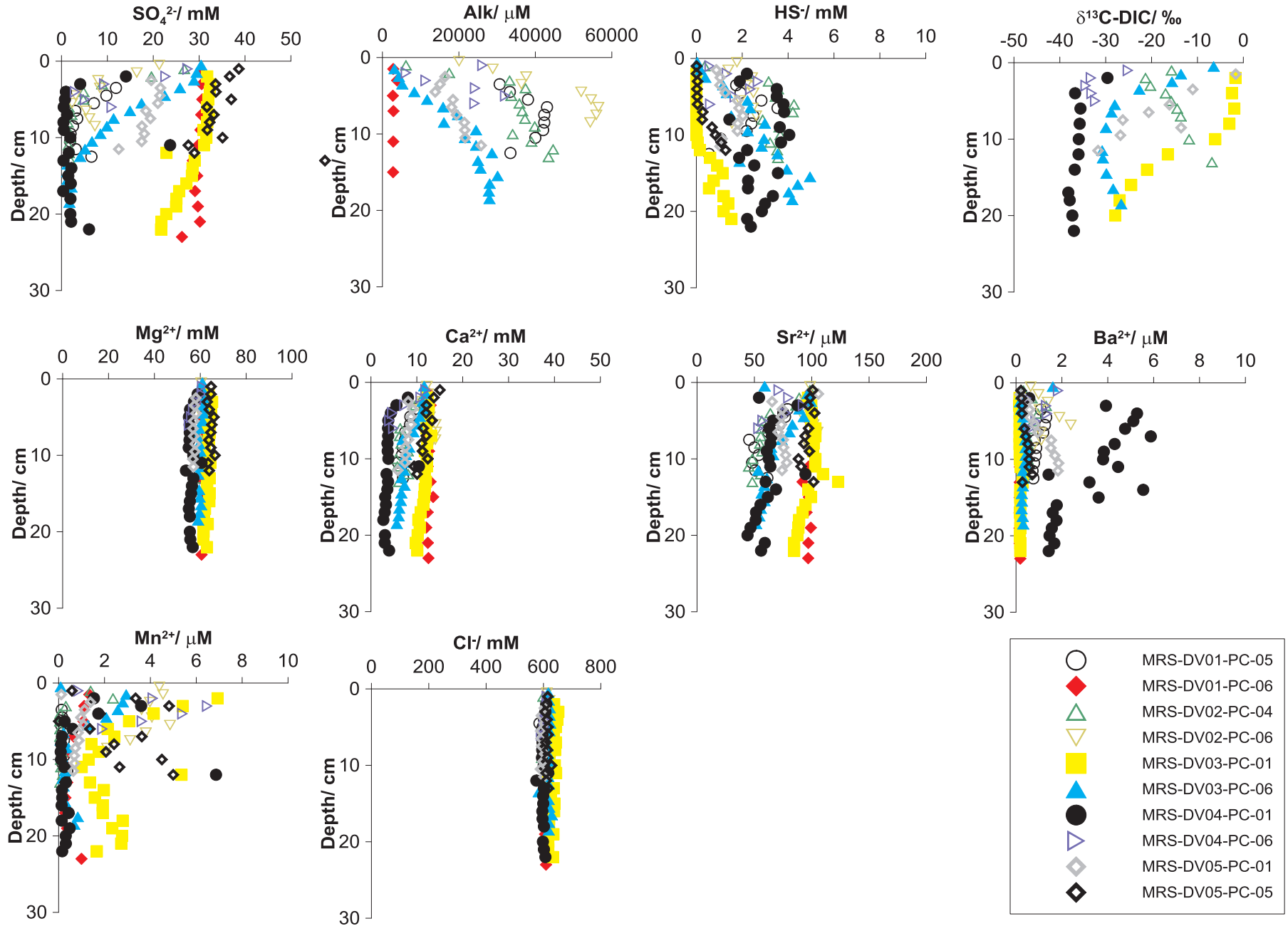

Fig. 7. Alkalinity and pore-water concentrations for chloride, sulfate, barium, magnesium, calcium, strontium nd manganese.

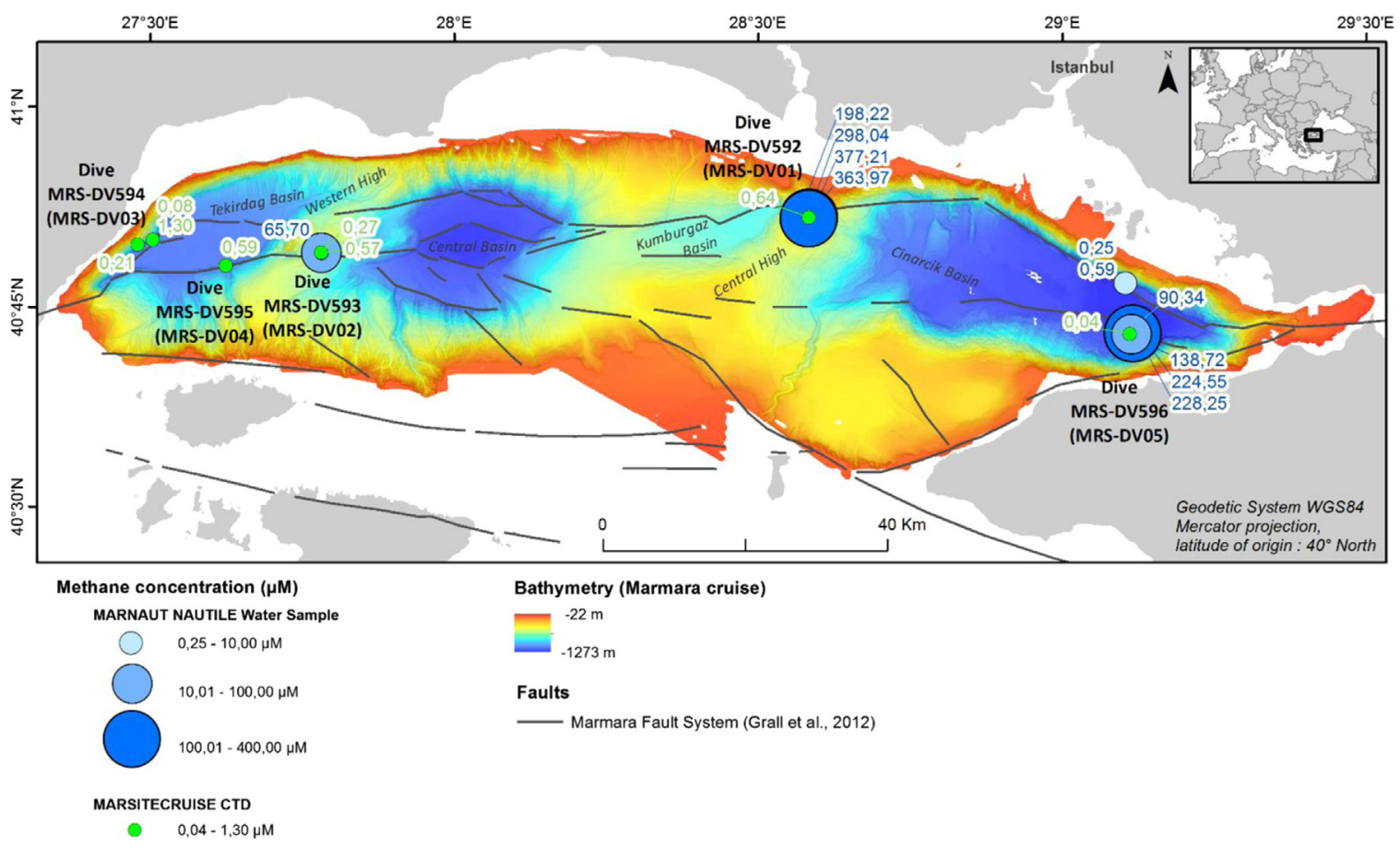

Fig. 8. Dissolved methane concentrations from CTD-Rosette and the Nautile-submersible samples. 
caution is advised when directly comparing single methane concentration values from an emission sites to another.

\subsection{Authigenic carbonates}

The authigenic carbonates collected during the five dives correspond to (1) carbonate crusts outcropping at the seafloor on Central High (MRS-DV01-01), Western High (MRS-DV02-02), and in the SE Tekirdag (MRS-DV04-01) and Cinarcik basins (MRS-DV05-01). These outcropping carbonates have been studied by Çağatay et al. (In this issue), Akhoudas et al. (In this issue) and Teichert et al. (2017). Beside, buried carbonate concretions were collected from push-cores (Table 3) on Central High (MRS-DV01-BC06, MRS-DV01-PC03, PC05 and PC08) and Western High (MRS-DV02-PC01).

Such authigenic carbonate concretions were previously collected during the Marnaut cruise at greater burial depths (down to $7.7 \mathrm{mbsf}$ ) from sedimentary cores in the different basins of the SoM (Chevalier et al., 2011; Crémiere et al., 2012; Zitter et al., 2008). The carbonate concretions from the MarsiteCruise push-cores collected in sediments from the subsurface down to $18 \mathrm{~cm}$, are $\mathrm{cm}$-sized, light-grey or yellowish colored, porous and they may include small shell fragments. Their total carbonate content ranges between 55\% and 84\% where aragonite dominates in association with minor proportions of highmagnesium calcite (HMC) (16-19 mol\% Mg, Table 3). Stoichiometric calcite corresponds to shell fragments or coccoliths (Fig. 9A) whereas acicular to prismatic aragonite (Fig. 9) and small subhedral crystals of HMC (Fig. 9A, B \& D) correspond to authigenic carbonates cementing the detrital minerals (quartz, feldspars) from the sedimentary matrix. Large aragonite crystals also developed in voids (Fig. 9C) or as deephoney yellow patches at the surface of the more aragonitic samples. Authigenic pyrite is always present and corresponds to the by-product of the sulfate reduction coupled to anaerobic methane oxidation through the production of hydrogen sulfide which reacts with iron to form iron sulfide (Yang et al., This issue). The oxygen isotopic compositions of the authigenic carbonate concretions $\left(+1.5<\delta^{18} \mathrm{O}\right.$ $\%$ VPDB $<+2.4$ ) from the Central and Western highs are about $1 \% 0$ lower compared to the isotopic equilibrium value calculated with the present-day bottom water $\delta^{18} \mathrm{O}$ and temperature. Similar results were obtained by Crémiere et al. (2012) and Çağatay et al. (in this issue), and attributed to the seepage of ${ }^{18} \mathrm{O}$-depleted fluids advected from the underlying sediment deposited during the last glacial period. However, aragonitic crusts from the Cinarcik Basin show near-equilibrium values indicating a very shallow precipitation near or at the seafloor. The carbon isotopic compositions of the authigenic carbonate concretions from the Central and Western High $\left(-23.8<\delta^{13} \mathrm{C} \%\right.$ VPDB $\left.<-8.2\right)$ vary widely from one site to another showing variable influence of methane derived carbon. Authigenic carbonate crusts from the Cinarcik Basin distinctly show the influence of microbial methane carbon with $\delta^{13} \mathrm{C}$ values as low as $-35.92 \%$ VPDB (Çağatay et al., In this issue; Crémiere et al., 2012). The $\delta^{13} \mathrm{C}$ values characterize precipitation of these carbonates with dissolved inorganic carbon (DIC) corresponding to variable mixtures of ${ }^{13} \mathrm{C}$-depleted DIC derived from methane oxidation (thermogenic or microbial methane) or from the oxidation of heavier hydrocarbon (Table 3). The ${ }^{13} \mathrm{C}$-rich carbonate concretions analyzed from core DV01-PC08 have likely been precipitated from the oxidation of thermogenic methane at deeper depth. This is in agreement with the dominant methane source at this location (Bourry et al., 2009; Ruffine et al., In this issue). The spatial $\delta^{13} \mathrm{C}$ distribution of authigenic carbonates depicts well both the patchiness of fluid venting and the variability of the composition and fluxes of the fluids that are controlled by the AOM and methanogenesis rates (Chatterjee et al., 2011).

\section{Conclusion}

Our study described a novel methodology to explore and sample cold seeps characterized by gas emissions, with an application to the Sea of Marmara. This methodology consists on a pre-dive water column acoustic survey for the selection of the most intense acoustic anomalies related to fluid emissions followed by a ROV dive. During the dive, an in situ Raman-spectrometry was used as decision-making for the selection of the seeps to be studied and the gas streams to be sampled. Thus, the methodology enabled us to build a versatile database. This work offers a broad general glimpse of the visited sites by ROV. In addition, the onboard analyses of the molecular composition of the collected gases together with the stable carbon isotope of methane were useful to capture the gas diversity and then organize the deployment of the other sampling tools like the collections of long sediment cores and the deployment of CTD-Rosette. Overall, the methodology has proved to be efficient in detecting gas emission sites and capturing spatial variations of fluid chemistry. Other cruises are needed in to order to further document on the seep diversity of the Sea of Marmara and to investigate the fate of methane into the water column; with the aim to start time series investigation. Indeed, methane has been measured at very high concentrations in the seawater near the gas emission sites, with pronounced step-down gradients when moving away from the emissions. This study also showed a correlation between the occurrence

Table 3

Mineralogy and chemical composition of the sampled carbonate concretions.

\begin{tabular}{|c|c|c|c|c|c|c|c|c|c|c|c|}
\hline $\begin{array}{l}\text { Carbonate sample, } \\
\text { depth/ cm }\end{array}$ & Latitude & Longitude & $\begin{array}{l}\text { water depth/ } \\
\text { m }\end{array}$ & $\mathrm{CaCO}_{3} \mathrm{wt} \%$ & Arag & LMC & HMC & d104 & $\begin{array}{l}\mathrm{mol} \% \\
\mathrm{MgCO}_{3}\end{array}$ & $\begin{array}{l}\delta^{18} \mathrm{O} \% \text { VPDB } \\
\text { (bulk) }\end{array}$ & $\begin{array}{l}\delta^{13} \mathrm{C} \% \text { VPDB } \\
\text { (bulk) }\end{array}$ \\
\hline \multicolumn{12}{|l|}{ Central High } \\
\hline MRS-DV01-BC06, 5-7 & $40^{\circ} 51.6909 \mathrm{~N}$ & $28^{\circ} 35.0011 \mathrm{E}$ & 334 & 69 & 82 & 6 & 12 & 2978 & 19 & 1,45 & $-23,79$ \\
\hline MRS-DV01-BC06, 7-9 & & & & 70 & 81 & 7 & 12 & 2978 & 19 & 2,27 & $-18,27$ \\
\hline MRS-DV01-BC06, 9-11 & & & & 74 & 67 & 9 & 25 & 2978 & 19 & 1,87 & $-20,95$ \\
\hline MRS-DV01-BC06, 11-13 & & & & 72 & 82 & 4 & 14 & 2982 & 18 & 1,85 & $-23,13$ \\
\hline MRS-DV01-BC06, $\geq 13$ & & & & 55 & 82 & 5 & 13 & 2986 & 16 & 2,30 & $-23,03$ \\
\hline MRS-DV01-PC03, 4-6 & $40^{\circ} 51.6912 \mathrm{~N}$ & $28^{\circ} 35.0020 \mathrm{E}$ & 328 & 76 & 86 & 7 & 8 & 2985 & 17 & 1,93 & $-18,68$ \\
\hline MRS-DV01-PC03, 8-10 & & & & 58 & 80 & 7 & 13 & 2986 & 16 & 1,93 & $-17,00$ \\
\hline MRS-DV01-PC03, 10-12 & & & & 69 & 74 & 6 & 20 & 2978 & 19 & 2,32 & $-17,39$ \\
\hline MRS-DV01-PC03, 12-14 & & & & 72 & 75 & 9 & 16 & 2981 & 18 & 1,64 & $-17,93$ \\
\hline MRS-DV01-PC03, 14-16 & & & & 74 & 80 & 8 & 12 & 2983 & 17 & 2,17 & $-16,40$ \\
\hline MRS-DV01-PC03, 16-18 & & & & 65 & 73 & 5 & 22 & 2983 & 17 & 2,38 & $-17,61$ \\
\hline MRS-DV01-PC08, 6-8 & $40^{\circ} 51.6908 \mathrm{~N}$ & $28^{\circ} 35.0018 \mathrm{E}$ & 328 & 74 & 53 & 7 & 40 & 2981 & 18 & 2,38 & $-8,21$ \\
\hline MRS-DV01-PC08, 8-10 & & & & 76 & 35 & 7 & 59 & 2982 & 18 & 2,47 & $-14,07$ \\
\hline MRS-DV01-PC08, 10-12 & & & & 69 & 79 & 6 & 15 & 2979 & 19 & 2,16 & $-14,00$ \\
\hline MRS-DV01-PC08, 12-14 & & & & 79 & 72 & 6 & 21 & 2981 & 18 & 2,43 & $-13,88$ \\
\hline \multicolumn{12}{|l|}{ Western High } \\
\hline MRS-DV02-PC01, 5-7 & $40^{\circ} 48.8645 \mathrm{~N}$ & $27^{\circ} 46.6612 \mathrm{E}$ & 643 & 84 & 97 & 3 & 0 & & & 2,03 & $-21,66$ \\
\hline MRS-DV02-PC08, 7-9 & & & & 74 & 98 & 2 & 0 & & & 2,42 & $-17,29$ \\
\hline
\end{tabular}



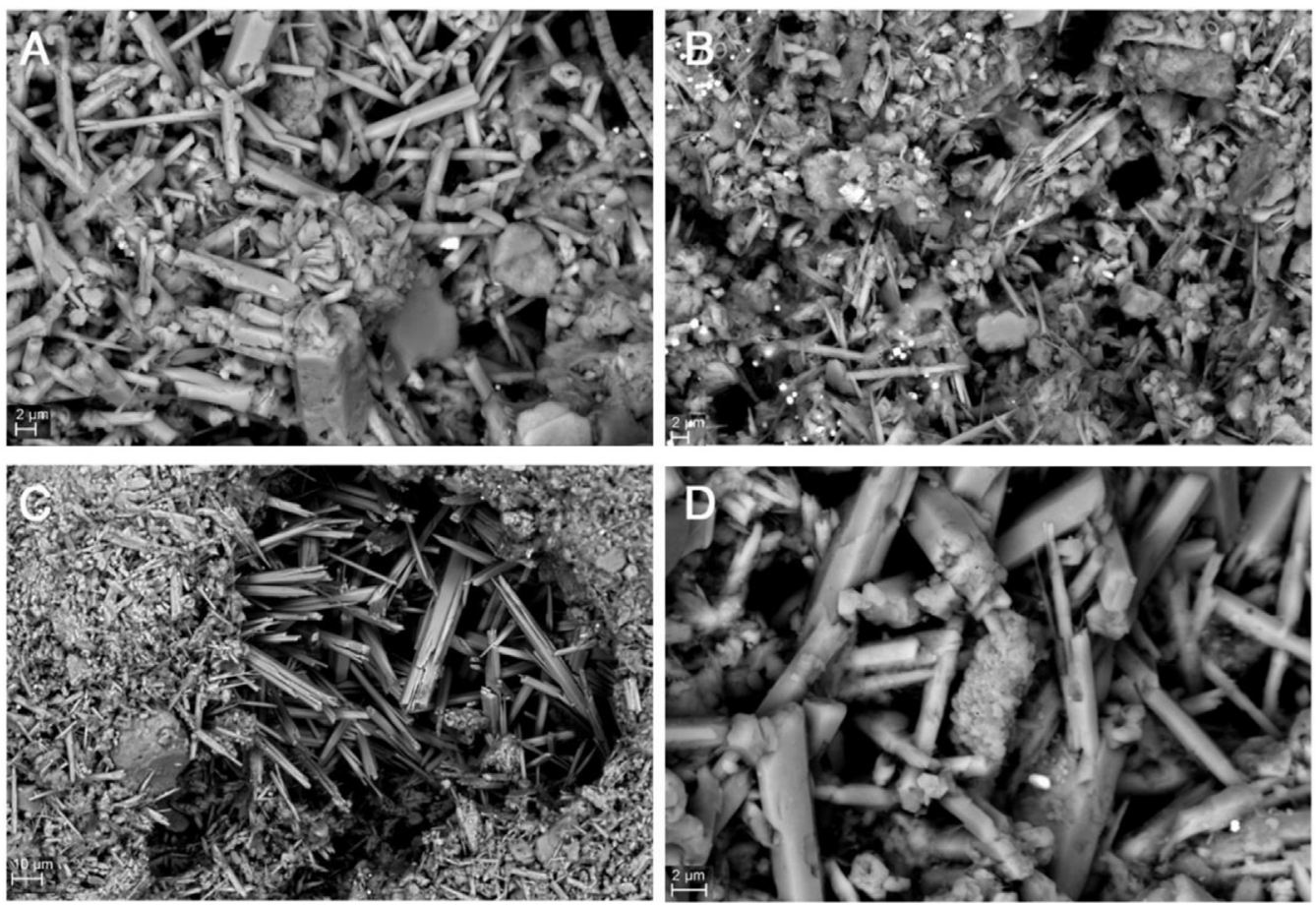

Fig. 9. SEM photographs (backscatter imagery) of selected carbonate concretions collected during the Marsite cruise. A: MRS-01PC03, 6-8 cm = cluster of small subhedral crystals of high magnesian calcite (HMC) cementing acicular to prismatic aragonite crystals, detrital grains and coccoliths. B: MRS-01-PC08, $6-8 \mathrm{~cm}=$ small subhedral crystals of HMC cementing acicular aragonite crystals, detrital grains and coccoliths; isolated crystals of pyrite appear with a high reflectivity. C: MRS-01-PC08, 12-14 cm = prismatic and acicular crystals of aragonite filling a small void. D: MRS-02-PC01, $7-9 \mathrm{~cm}=$ prismatic aragonite crystals with a cluster of small HMC crystals (suggesting coating aragonite) at the center. of gas emissions and the fast depletion of seawater sulfate within upper sedimentary column, suggesting that AOM plays in important role in preventing complete release of methane into the water column in the SoM. Thus, constraining the methane budget along the NAF and inherited faults is also necessary to assess the role of active faults in transferring fluids from deep depth to the seafloor. The outcomes would be valuable to further decipher the link between fluid flow and transformation, and the seismicity of the Marmara region.

\section{Acknowledgements}

We thank the captain and his crew on-board the $R V$ Pourquoi pas? as well as the team of the ROV Victor- 6000 crew for their technical support and advices. Financial support was provided by the European programme «MARsite», under the call ENV.2012.6.4-2: "Long-term monitoring experiment in geologically active regions of Europe prone to natural hazards: the Supersite concept". This work was also supported by (1) the "Laboratoire d'Excellence" LabexMER (ANR-10-LABX19) through the projects called MicroGaMa and MISS Marmara, cofunded by a grant from the French government under the program "Investissements d'Avenir", and (2) the ANR- Institut Carnot call OI-112 «Institut CARNOT Ifremer-EDROME 2015».

\section{References}

Akhoudas, C., Chevalier, N., Blanc-Valleron, M.-.M., Klein, V., Mendez, M., Demange, J., Dalliah, S., Rommevaux, V., Boudouma, O., Pierre, C., Ruffine, C., L., 2017. Methanederived stromatolitic formation at cold seeps in the western basin of the Sea of Marmara: Evidence from a mineralogical, isotopic and molecular geochemical approach. Deep Sea Research Part II: Topical Studies in Oceanography (in this issue).

Bayrakci, G., Scalabrin, C., Dupre, S., Leblond, I., Tary, J.B., Lanteri, N., Augustin, J.M., Berger, L., Cros, E., Ogor, A., Tsabaris, C., Lescanne, M., Geli, L., 2014. Acoustic monitoring of gas emissions from the seafloor. Part II: a case study from the Sea of Marmara. Mar. Geophys. Res. 35, 211-229.

Boetius, A., Wenzhofer, F., 2013. Seafloor oxygen consumption fuelled by methane from cold seeps. Nat. Geosci. 6, 725-734.

Borowski, W.S., Paull, C.K., Ussler, W., 1996. Marine pore-water sulfate profiles indicate in situ methane flux from underlying gas hydrate. Geology 24, 655-658.

Bourry, C., Chazallon, B., Charlou, J.L., Donval, J.P., Ruffine, L., Henry, P., Geli, Le, Cağatay, M.N., Inan, S., Moreau, M., 2009. Free gas and gas hydrates from the Sea of Marmara, Turkey chemical and structural characterization. Chem. Geol. 264, 197-206.

Burnard, P., Bourlange, S., Henry, P., Geli, L., Tryon, M., Sengör, A., Özeren, M., Çagatay,
M., 2012. Constraints on fluid origins and migration velocities along the Marmara Main Fault (Sea of Marmara, Turkey) using helium isotopes. Earth Planet. Sci. Lett. $341,68-78$.

Cağatay, M.N., Ozcan, M., Gungor, E., 2004. Pore-water and sediment geochemistry in the Marmara Sea (Turkey): early diagenesis and diffusive fluxes. Geochem.-Explor. Environ. Anal. 4, 213-225.

Çağatay, Namik M., Yildiz, Guliz, Bayon, Germain, Ruffine, Livio, Henry, Pierre, In this issue. Seafloor authigenic carbonate crusts along the submerged part of the North Anatolian Fault in the Sea of Marmara: Mineralogy, geochemistry, textures and genesis. Deep Sea Research Part II: Topical Studies in Oceanography, http://doi.org/ 10.1016/j.dsr2.2017.09.003.

Calvert, S., Pedersen, T., 1993. Geochemistry of recent oxic and anoxic marine sediments: implications for the geological record. Mar. Geol. 113, 67-88.

Chatterjee, S., Dickens, G.R., Bhatnagar, G., Chapman, W.G., Dugan, B., Snyder, G.T., Hirasaki, G.J., 2011. Pore water sulfate, alkalinity, and carbon isotope profiles in shallow sediment above marine gas hydrate systems: a numerical modeling perspective. J. Geophys. Res.-Solid Earth 116.

Chevalier, N., Bouloubassi, I., Birgel, D., Crémière, A., Taphanel, M.-H., Pierre, C., 2011. Authigenic carbonates at cold seeps in the Marmara Sea (Turkey): a lipid biomarker and stable carbon and oxygen isotope investigation. Mar. Geol. 288, 112-121.

Chevalier, N., Bouloubassi, I., Birgel, D., Taphanel, M.H., López-García, P., 2013. Microbial methane turnover at Marmara Sea cold seeps: a combined 16S rRNA and lipid biomarker investigation. Geobiology 11, 55-71.

Chuang, P.-C., Dale, A.W., Wallmann, K., Haeckel, M., Yang, T.F., Chen, N.-C., Chen, H. C., Chen, H.-W., Lin, S., Sun, C.-H., You, C.-F., Horng, C.-S., Wang, Y., Chung, S.-H., 2013. Relating sulfate and methane dynamics to geology: Accretionary prism offshore SW Taiwan. Geochem. Geophys. Geosystems 14, 2523-2545.

Cline, J.D., 1969. Spectrophotometric determination of hydrogen sulfide in natural waters. Limnol. Oceanogr. 14, 454-458.

Crémiere, A., Pierre, C., Blanc-Valleron, M.-M., Zitter, T., Çağatay, M.N., Henry, P., 2012. Methane-derived authigenic carbonates along the North Anatolian fault system in the Sea of Marmara (Turkey). Deep-Sea Res. Part I-Oceanogr. Res. Pap. 66, 114-130.

Crémière, A., Bayon, G., Ponzevera, E., Pierre, C., 2013. Paleo-environmental controls on cold seep carbonate authigenesis in the Sea of Marmara. Earth Planet. Sci. Lett. 376, 200-211.

Deusner, C., Holler, T., Arnold, G.L., Bernasconi, S.M., Formolo, M.J., Brunner, B., 2014 Sulfur and oxygen isotope fractionation during sulfate reduction coupled to anaerobic oxidation of methane is dependent on methane concentration. Earth Planet. Sci. Lett. 399, 61-73.

Dupré, S., Scalabrin, C., Géli, L., Henry, P., Grall, C., Tary, J., Cağatay, M., Imren, C., 2010. The MARMESONET Scientific Party Team (2010b) Widespread gas emissions in the Sea of Marmara in relation with the tectonic and sedimentary environments: results from shipborne multibeam echosounder water column imagery (MARMESONET expedition, 2009). Eur. Geosci. Union Gen. Assem. 12, 9429.

Dupré, S., Scalabrin, C., Grall, C., Augustin, J.-M., Henry, P., Sengor, A.M.C., Goeruer, N., Çağatay, M.N., Geli, L., 2015. Tectonic and sedimentary controls on widespread gas emissions in the Sea of Marmara: results from systematic, shipborne multibeam echo sounder water column imaging. J. Geophys. Res.-Solid Earth 120, 2891-2912.

Embriaco, D., Marinaro, G., Frugoni, F., Monna, S., Etiope, G., Gasperini, L., Polonia, A. Del Bianco, F., Çağatay, M.N., Ulgen, U.B., Favali, P., 2014. Monitoring of gas and 
seismic energy release by multiparametric benthic observatory along the North Anatolian Fault in the Sea of Marmara (NW Turkey). Geophys. J. Int. 196, 850-866.

Foucher, J.P., Westbrook, G.K., Boetius, A., Ceramicola, S., Dupre, S., Mascle, J., Mienert, J., Pfannkuche, O., Pierre, C., Praeg, D., 2009. Structure and drivers of cold seep ecosystems. Oceanography $22,92-109$.

Gasperini, L., Polonia, A., Bortoluzzi, G., Henry, P., Le Pichon, X., Tryon, M., Çağatay, N., Geli, L., 2011. How far did the surface rupture of the 1999 Izmit earthquake reach in Sea of Marmara? Tectonics 30.

Géli, L., Henry, P., Zitter, T., Dupré, S., Tryon, M., Cagatay, M., de Lépinay, B., Le Pichon, X., engör, A., Görür, N., 2008. Gas emissions and active tectonics within the submerged section of the North Anatolian Fault zone in the Sea of Marmara. Earth Planet. Sci. Lett. 274, 34-39.

Grall, C., Henry, P., Thomas, Y., Westbrook, G.K., Cağatay, M.N., Marsset, B., Saritas, H., Cifci, G., Geli, L., 2013. Slip rate estimation along the western segment of the Main Marmara Fault over the last 405-490 ka by correlating mass transport deposits. Tectonics 32 .

Halbach, P., Holzbecher, E., Reichel, T., Moche, R., 2004. Migration of the sulphatemethane reaction zone in marine sediments of the Sea of Marmara - can this mechanism be tectonically induced? Chem. Geol. 205, 73-82.

Holler, T., Wegener, G., Niemann, H., Deusner, C., Ferdelman, T.G., Boetius, A., Brunner, B., Widdel, F., 2011. Carbon and sulfur back flux during anaerobic microbial oxidation of methane and coupled sulfate reduction. Proc. Natl. Acad. Sci. USA 108, E1484-E1490.

Holler, T., Wegener, G., Niemann, H., Deusner, C., Ferdelman, T.G., Boetius, A., Brunner, B., Widdel, F., 2012. Carbon and sulfur back flux during anaerobic microbial oxidation of methane and coupled sulfate reduction. Proc. Natl. Acad. Sci. USA 109, 21170-21173 (vol 108, pg E1484, 2012).

Kvenvolden, K.A., 1988. Methane hydrate - A major reservoir of carbon in the shallow geosphere. Chem. Geol. 71, 41-51.

Le Pichon, X., Sengor, A.M.C., Demirbag, E., Rangin, C., Imren, C., Armijo, R., Gorur, N., Çă̆atay, N., de Lepinay, B.M., Meyer, B., Saatcilar, R., Tok, B., 2001. The active main Marmara fault. Earth Planet. Sci. Lett. 192, 595-616.

Lin, Z., Sun, X., Peckmann, J., Lu, Y., Xu, L., Strauss, H., Zhou, H., Gong, J., Lu, H., Teichert, B.M.A., 2016. How sulfate-driven anaerobic oxidation of methane affects the sulfur isotopic composition of pyrite: a SIMS study from the South China Sea. Chem. Geol. 440, 26-41.

Mau, S., Romer, M., Torres, M.E., Bussmann, I., Pape, T., Damm, E., Geprags, P., Wintersteller, P., Hsu, C.W., Loher, M., Bohrmann, G., 2017. Widespread methane seepage along the continental margin off Svalbard - from Bjornoya to Kongsfjorden. Sci. Rep. 7.

Peron, O., Rinnert, E., Colas, F., Lehaitre, M., Compere, C., 2010. First steps of in situ surface-enhanced Raman scattering during shipboard experiments. Appl. Spectrosc. 64, 1086-1093.

Pierre, C., Demange, J., Blanc-Valleron, M.-M., Dupré, S., 2017. Authigenic carbonate mounds from active methane seeps on the southern Aquitaine Shelf (Bay of Biscay, France): evidence for anaerobic oxidation of biogenic methane and submarine groundwater discharge during formation. Cont. Shelf Res. 133, 13-25.

Ruffine, L., Germain, Y., Polonia, A., de Prunele, A., Croguennec, C., Donval, J.-P., PitelRoudaut, M., Ponzevera, E., Caprais, J.-C., Brandily, C., Grall, C., Bollinger, C., Geli,
L., Gasperini, L., 2015. Pore water geochemistry at two seismogenic areas in the Sea of Marmara. Geochem. Geophys. Geosystems 16, 2038-2057.

Ruffine, L., Donval, J.-.P., Croguennec, C., Burnard, P., Lu, H., Germain, Y., Legoix, L.N., Bignon, L., Çağatay, M.N., Marty, B., Madre, D., Pitel-Roudaut, M., Henry, P., Géli, L., 2017. Multiple gas reservoirs are responsible for the gas emissions along the Marmara fault network. Deep Sea Research Part II: Topical Studies in Oceanography (in this issue).

Sahling, H., Rickert, D., Lee, R.W., Linke, P., Suess, E., 2002. Macrofaunal community structure and sulfide flux at gas hydrate deposits from the Cascadia convergent margin, NE Pacific. Mar. Ecol. Progress. Ser. 231, 121-138.

Sassen, R., Roberts, H.H., Aharon, P., Larkin, J., Chinn, E.W., Carney, R., 1993. Chemosynthetic bacterial mats at cold hydrocarbon seeps, Gulf of Mexico continental slope. Org. Geochem. 20, 77-89.

Seeberg-Elverfeldt, J., Schlüter, M., Feseker, T., Kölling, M., 2005. Rhizon sampling of pore waters near the sediment/water interface of aquatic systems. Limnol. Oceanogr: Methods 3, 361-371.

Sibuet, M., Olu, K., 1998. Biogeography, biodiversity and fluid dependence of deep-sea cold-seep communities at active and passive margins. Deep Sea Res. Part II: Top. Stud. Oceanogr. 45, 517-567.

Suess, E., 2014. Marine cold seeps and their manifestations: geological control, biogeochemical criteria and environmental conditions. Int. J. Earth Sci. 103, 1889-1916.

Sultan, N., Garziglia, S., Ruffine, L., 2016. New insights into the transport processes controlling the sulfate-methane-transition-zone near methane vents. Sci. Rep. 6.

Talukder, A.R., 2012. Review of submarine cold seep plumbing systems: leakage to seepage and venting. Terra Nova 24, 255-272.

Teichert, B.M.A., Chevalier, N., Gussone, N., Bayon, Germain, Ponzevera, Emmanuel, Ruffine, Livio, Strauss, H., 2017. Sulfate-dependent anaerobic oxidation of methane at a highly dynamic bubbling site in the Eastern Sea of Marmara (Çinarcik Basin). Deep-Sea Research Part II: Topical Studies in Oceanography, http://doi.org/10. 1016/j.dsr2.2017.11.014. (in this issue)

Thomson, J., Nixon, S., Croudace, I.W., Pedersen, T.F., Brown, L., Cook, G.T., MacKenzie, A.B., 2001. Redox-sensitive element uptake in north-east Atlantic Ocean sediments (Benthic Boundary Layer Experiment sites). Earth Planet. Sci. Lett. 184, 535-547.

Tryon, M.D., Henry, P., Cağatay, M.N., Zitter, T.A.C., Geli, L., Gasperini, L., Burnard, P., Bourlange, S., Grall, C., 2010. Pore fluid chemistry of the North Anatolian Fault Zone in the Sea of Marmara: a diversity of sources and processes. Geochem. Geophys. Geosystems 11.

Westbrook, G.K., Thatcher, K.E., Rohling, E.J., Piotrowski, A.M., Palike, H., Osborne, A.H., Nisbet, E.G., Minshull, T.A., Lanoiselle, M., James, R.H., Huhnerbach, V., Green, D., Fisher, R.E., Crocker, A.J., Chabert, A., Bolton, C., Beszczynska-Moller, A., Berndt, C., Aquilina, A., 2009. Escape of methane gas from the seabed along the West Spitsbergen continental margin. Geophys. Res. Lett. 36.

Yang, H., Lu, H., Ruffine, L., In this issue. Geochemical Characteristics of Fe in Sediment from the Sea of Marmara. Deep Sea Research Part II: Topical Studies in Oceanography.

Zitter, T., Henry, P., Aloisi, G., Delaygue, G., Çagatay, M., Mercier de Lepinay, B., AlSamir, M., Fornacciari, F., Tesmer, M., Pekdeger, A., 2008. Cold seeps along the main Marmara fault in the Sea of Marmara (Turkey). Deep-Sea Res. Part I 55, 552-570. 